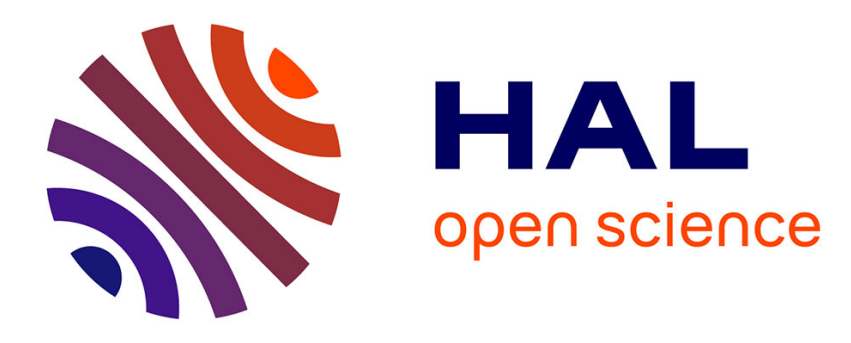

\title{
A simplified test of cornstalk nitrate for better $\mathrm{N}$ management
}

\author{
Ramón Isla, Alfred M. Blackmer
}

\section{To cite this version:}

Ramón Isla, Alfred M. Blackmer. A simplified test of cornstalk nitrate for better N management. Agronomy for Sustainable Development, 2007, 27 (3), pp.237-241. hal-00886378

\section{HAL Id: hal-00886378 https://hal.science/hal-00886378}

Submitted on 1 Jan 2007

HAL is a multi-disciplinary open access archive for the deposit and dissemination of scientific research documents, whether they are published or not. The documents may come from teaching and research institutions in France or abroad, or from public or private research centers.
L'archive ouverte pluridisciplinaire HAL, est destinée au dépôt et à la diffusion de documents scientifiques de niveau recherche, publiés ou non, émanant des établissements d'enseignement et de recherche français ou étrangers, des laboratoires publics ou privés. 


\title{
A simplified test of cornstalk nitrate for better $\mathbf{N}$ management
}

\author{
Ramón ISLA $^{\mathrm{a} *}$, Alfred M. BLACKMER ${ }^{\mathrm{b}}$ \\ ${ }^{a}$ Soils and Irrigation Department, Agri-food Research and Technology Center of Aragón (CITA), Government of Aragón, Zaragoza, Spain. Apdo. 727, 50080, \\ Zaragoza, Spain \\ ${ }^{\mathrm{b}}$ In Memory, Department of Agronomy, Iowa State University, Ames Iowa, 50011, USA
}

(Accepted 27 February 2007)

\begin{abstract}
The end-of-season test for cornstalk nitrate gives site-specific information about crop $\mathrm{N}$ sufficiency and $\mathrm{N}$ excess. It is a very valuable decision tool for increasing the sustainability of $\mathrm{N}$ fertilizer practices. However, little information is available about the possibility of simplifying this tissue test and the extent to which results of the test are influenced by deviations from recommended sampling procedures. This information would be very valuable to promote the acceptance and use of the test by maize growers. Here we analyzed stalk nitrate concentrations from stalks collected in several experimental maize plots receiving different rates of $\mathrm{N}$ fertilizer ranging from deficient (zero nitrogen) to excess $\left(350 \mathrm{~kg} \mathrm{~N} \mathrm{ha}^{-1}\right)$. Our results show that nitrate concentrations of $2.5-\mathrm{cm}$ segments of stalk with and without nodes showed no significant differences, and no special care during stalk sampling must be taken. In addition, although $\mathrm{NO}_{3}-\mathrm{N}_{\text {concentrations in pith tissue }}$ are, on average, $29 \%$ higher than in the rind, the relative amounts of nitrate in pith (18\%) and rind (82\%) revealed little need for efforts to ensure that the ratios of pith and rind were not altered during sampling or analysis. Nitrate concentrations tended to decrease by $4 \%$ for each $\mathrm{cm}$ of deviation above the height normally sampled. Overall, the results presented indicate the robustness of the test to small deviations during sampling procedures and that a minimum of 10 stalk segments are necessary to adequately assess $\mathrm{N}$ sufficiency. Finally, it is feasible to decrease the length of the sampled stalk to segments of $4 \mathrm{~cm}$ if they are centered about $25 \mathrm{~cm}$ from the ground, to avoid large deviation due to the stem nitrate gradient observed. Our findings can help to promote and simplify the cornstalk nitrate test, improving $\mathrm{N}$ management and decreasing the negative environmental impact of excessive fertilizer applications.
\end{abstract}

maize / nitrogen sufficiency / nitrate / plant sampling / plant analysis / fertilizer

\section{INTRODUCTION}

The end-of-season test for cornstalk nitrate is a tool for characterizing $\mathrm{N}$ sufficiency and excess in maize and its use is intended to optimize $\mathrm{N}$ management in maize (Binford et al., 1990, 1992). The test is based on the knowledge that nitrate tends to accumulate in plants when $\mathrm{N}$ is in excess in the soil (Murphy and Smith, 1967). This shoot nitrate accumulation was also described in wheat under high-nitrate conditions (Zhen and Leigh, 1990). Other work indicates that the excess of nitrate is accumulated in the vacuole as a storage pool that can be available if soil nitrogen becomes limiting for growth (Granstedt and Huffaker, 1982). The potential utility of these tests relating yield to plant nitrate concentration has been demonstrated for wheat (Justes et al., 1994) and rice (Sheehy et al., 1998).

The cornstalk test for nitrate can be used to help interpret the results of $\mathrm{N}$-response trials or to make site-specific evaluations of $\mathrm{N}$ management practices used in production agriculture, and can be used to study the $\mathrm{N}$ fertilizer management on a watershed scale in studies aimed at reducing the environmental impact of $\mathrm{N}$ fertilizer (Balkcom et al., 2003). Recent studies indicate a causal relationship between nitrate pollution

* Corresponding author: risla@aragon.es in body-waters and drainage from nearby agricultural areas (Deutsch et al., 2006; Isidoro et al., 2006). Others indicate the necessity of using soil or plant tests to increase the sustainability of $\mathrm{N}$ fertilizer practices (Abad et al., 2006). The mentioned test is unique among tissue tests for corn because it can characterize the degrees of excess or deficiency of N. Moreover, the critical nitrate concentration (i.e., the concentration that distinguishes inadequate from adequate supplies) seems to be remarkably constant across corn hybrids and environmental conditions since it was obtained by pooling data from different hybrids and across different soil conditions (Binford et al., 1990). Current interpretations are that $\mathrm{N}$ sufficiency should be considered low if stalk nitrate concentrations are 0 to $249 \mathrm{mg}$ $\mathrm{N} / \mathrm{kg}$, marginal if they are 250 to $699 \mathrm{mg} \mathrm{N} / \mathrm{kg}$, optimal if they are 700 to $1999 \mathrm{mg} \mathrm{N} / \mathrm{kg}$, and excess if they are $>2000 \mathrm{mg} / \mathrm{kg}$ (Blackmer and Mallarino, 1997).

The recommended sampling procedure for this test involves collecting fifteen $20-\mathrm{cm}$ segments located at 15 to $35 \mathrm{~cm}$ above the ground. The recommendation to sample this segment essentially follows arbitrary decisions made during initial exploratory studies to analyze the potential of a $\mathrm{N}$ test based on stalk nitrate concentrations. Once the utility of the test has been established, there is a need for a better understanding of how minor deviations in the sampling procedure influence the 
results of the test. The effects of minor deviations in the sampling procedure deserve special attention in situations where interpretations are based on published calibrations rather than on relative differences observed in a single study. Recently, Wilhelm et al., (2005) addressed some of these questions related to the stalk test and concluded the robustness of the test to minor deviations in the length of the stalk during sampling.

Knowledge of how nitrate is partitioned between the pith and rind of cornstalks enables assessment of potential problems caused by insect damage or separation of materials during sampling, grinding or analysis because the different tissues have different densities. The pith is anatomically composed of large parenchymatic cells, while the rind is a combination of epidermal, sclerenchyma and vascular bundles. The extent to which nitrate concentrations vary with height above the ground determines the need for accuracy when samples are collected. Measured variability in nitrate concentration among stalks collected from a single field area with a homogeneous soil $\mathrm{N}$ regime and environmental conditions determines the number of stalks needed to attain the desired level of confidence in assessment of $\mathrm{N}$ status.

The primary objective of this study was to assess the extent to which results of the test are influenced by the number of nodes included in the sample, loss of pith, variation in height of sample collection and number of stalk segments collected. The recommended sampling usually results in one or two nodes per stalk segment. Therefore, there is a need to evaluate the potential benefits of adjusting the sampling procedure to include either one or two nodes. A secondary objective was to evaluate the feasibility of reducing the length of the stalk segment sampled, which would allow a cheaper and faster method to assess sample nitrate concentrations. With the exception of the work of Wilhelm et al. (2005), which addressed the effect of small deviations in the length of the stalk during sampling, the other questions have not been sufficiently studied.

This study was conducted with the idea that the end-ofseason test for cornstalk nitrate involves collecting many individual stalk segments to form a single sample that represents a given area. It was assumed that only areas judged to be reasonably uniform would be included in the sample because, as pointed out by Blackmer and White (1998), little useful information is obtained by collecting a sample across two areas expected to differ significantly. It was expected that a functional definition for "reasonably uniform soil" could be provided by amounts of variability among individual plants usually found in plots of $\mathrm{N}$-response trials. The specific design of this study recognizes that the variability due to the sampling technique must be assessed before the variability in $\mathrm{N}$ status among individual plants can be discussed.

\section{MATERIALS AND METHODS}

The plant material used in this study was obtained from maize plots of N-response trials carried out in different fields during 1997 in Iowa State (USA), where different rates of nitrogen were applied. Other than fertilizer application and sampling, all plots were managed by practices commonly used in Iowa maize fields. The fields from which the cornstalk were collected were winter-fertilized the previous year using ammonium anhydrous fertilizer and the N-response plots were sidedressed with a variable $\mathrm{N}$ rate ranging from zero to excess $\left(350 \mathrm{~kg} \mathrm{~N} \mathrm{ha}^{-1}\right)$ of nitrogen after planting around the V6-V8 stage. The cornstalks were collected 1-3 weeks after a black layer had formed on the majority of kernels. This allows one to get plant material from $\mathrm{N}$-deficient to $\mathrm{N}$-excessive plots according to the values suggested by Binford et al. (1992). In all cases the sheaths were removed from the cornstalk, ovendried to $65^{\circ} \mathrm{C}$ until constant weight, and ground in a Wiley mill with a $1.0-\mathrm{mm}$ screen. A subsample of approximately $1.5 \mathrm{~g}$ was extracted with $50 \mathrm{~mL}$ of $\mathrm{AlSO}_{4}$, shaken for $15 \mathrm{~min}$, filtered through a Whatman no. 1 paper, and analyzed using a selective nitrate electrode (Orion model 93-07, Boston, USA). The use of a nitrate-specific ion electrode to determine stalk nitrate concentrations was proposed as economically advantageous by Wilhelm et al., (2000). Paired comparisons were made using the TTEST procedure and the lineal regressions and the hypotheses tests of the regression parameters were performed using the REG procedure of SAS/STAT software, Version 9.1.

\subsection{Distribution of nitrate in the cornstalk}

To determine the differences between the nitrate in the rind and the pith, 10 cornstalks from 6 sites ranging from low to high soil-nitrate concentrations were selected. Plant material from each cornstalk segment was separated into four parts: node-rind, node-pith, internode-rind and internode-pith. The four portions from each of the ten segments were pooled to form a composite sample, dried and analyzed following the procedure cited above.

To determine the distribution of nitrate along the cornstalk, samples from 36 sites ( 15 to 20 cornstalks each) ranging from low to high soil-nitrate concentration were selected. Each cornstalk was divided into three segments of the same length from the lower (from 15 to $21.5 \mathrm{~cm}$ from the soil surface), middle (from 21.5 to $28 \mathrm{~cm}$ ) and upper (from 28 to $35 \mathrm{~cm}$ ) parts of the cornstalk. Each portion composed of 15 to 20 segments from each site was pooled, weighted and analyzed for nitrate separately.

\subsection{Variability among cornstalks}

Approximately fifteen individual standard cornstalks were collected from 10 different sites following the sampling recommendations (Binford et al., 1990). Each individual cornstalk was ground separately and analyzed following the same procedure cited above. This allows the calculation of the relationship between the within-site standard deviation $(S)$ for nitrate concentration in the cornstalk and the mean concentration for nitrate. The confidence interval (CI) for a given significance level, $\alpha$, and for a sample with $n$ cornstalks, and $S$ 


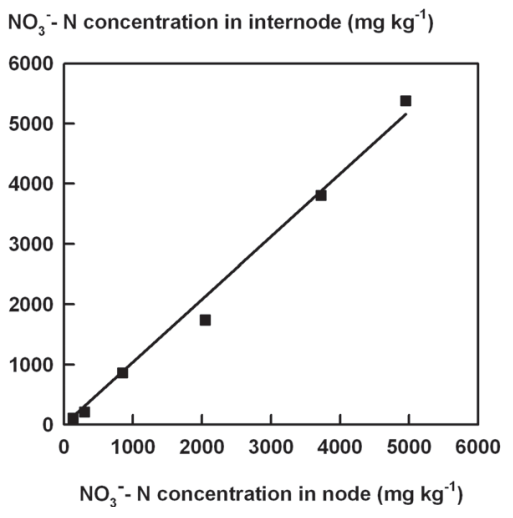

Figure 1. Relationship between the $\mathrm{NO}_{3}-\mathrm{N}$ concentration $\left(\mathrm{mg} \mathrm{kg}^{-1}\right)$ in the node and internode of the cornstalk. $\mathrm{Y}=1.04 \mathrm{X}, \mathrm{R}^{2}=0.99$.

as standard deviation of the mean, was calculated using the standard equation:

$$
C I=t_{\alpha, n-1} \frac{S}{\sqrt{n}} .
$$

\subsection{Large versus small samples}

Approximately fifteen individual standard cornstalks were collected from 15 different sites following the sampling recommendations (Binford et al., 1990). Each segment was cut into two pieces, one of $4 \mathrm{~cm}$ length and the other of $16 \mathrm{~cm}$ length. No special care was taken with which part of the stalk segment was cut into the small portion. All the small and large pieces from each site were pooled separately to form composite samples called small and large. The standard cornstalk (20-cm length) nitrate concentration was obtained as a weighted average nitrate concentration of the small and large samples. The samples were ground and analyzed using the same procedure cited above.

\section{RESULTS AND DISCUSSION}

\subsection{Distribution of nitrate in the cornstalk}

Figure 1 shows that nitrate concentrations in $2.5-\mathrm{cm}$ stalk segments centered in the internodes were significantly $(P<$ $0.001)$ correlated with the concentration of nitrate in $2.5-\mathrm{cm}$ segments cut halfway between internodes. Because the intercept of the linear model was not significantly different $(P>$ 0.05) from zero, a zero-intercept model was fitted (Fig. 1). The slope of the regression (slope $=1.04$ ) was not significantly $(P>0.1)$ different from one. In addition, differences between the node and internode values were not significantly $(P>0.1)$ different from zero in a paired comparison (t-test). These findings indicate, in agreement with the results obtained by Wilhelm et al. (2005), that differences in nitrate concentration between nodes and internodes are not significant, especially if it is recognized that commonly observed stalk nitrate concentrations range from $<10$ to $>10000 \mathrm{mg} \mathrm{N} \mathrm{kg}^{-1}$.

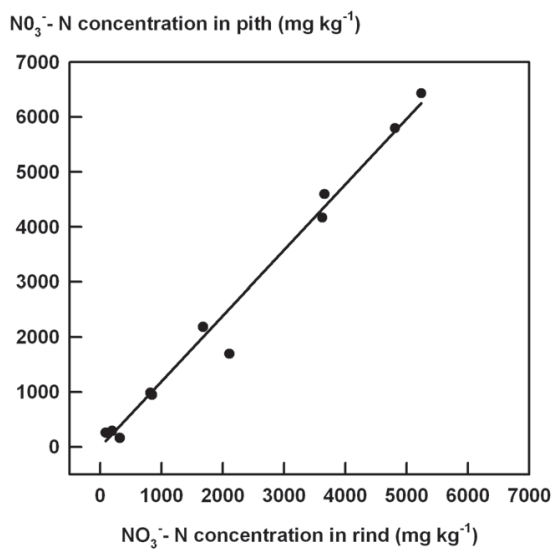

Figure 2. Relationship between the $\mathrm{NO}_{3}-\mathrm{N}$ concentration $\left(\mathrm{mg} \mathrm{kg}^{-1}\right)$ in the rind and the pith of the cornstalk. $\mathrm{Y}=1.19 \mathrm{X}, \mathrm{R}^{2}=0.98$.

Nitrate concentrations in the pith were significantly correlated $(P<0.001)$ with nitrate concentrations in the outer rind of the stalks (Fig. 2). The non-intercept model was fitted to the data because the intercept was not significantly different from zero $(P>0.05)$. The slope indicates that concentrations in the pith tended to be $19 \%$ higher than in the rind. Although this difference is easily measurable, its practical importance is diminished by the finding that the rind contained about 5.5 times more dry matter than the pith (data not shown).

These results indicate that the loss of the pith in a few stalks of the sample due to insect damage or diseases has a relatively small effect on the observed concentrations of nitrate in cornstalks. These findings also suggest that there is little need for special efforts to retain exact proportions of rind and pith during sample collection and analysis.

Nitrate concentrations within normally-sampled stalk segments tended to decrease with increasing height above the ground (Fig. 3). These findings are consistent with the reports of Friedrich et al. (1979) and Wilhelm et al. (2005), who found that nitrate concentrations tended to decrease with increasing height in corn plants and is consistent with the knowledge that nutrient translocation after physiological maturity goes from top to bottom within each individual plant. The slopes of the linear regressions shown in Figure 3 indicate that the relative concentrations of nitrate in the upper third of the normal samples tended to be about $55 \%$ of those found in the lower third. When cutting, a displacement of $1 \mathrm{~cm}$ causes an error of about $40 \mathrm{mg} \mathrm{N} \mathrm{kg} \mathrm{N}^{-1}$ in the $\mathrm{N}$ concentrations if the usual sample has a nitrate concentration around $1000 \mathrm{mg} \mathrm{N} \mathrm{kg}^{-1}$. Thus, errors due to the height of sampling seem to be relatively unimportant except when stalk nitrate concentrations are less than $250 \mathrm{mg} \mathrm{N} \mathrm{kg}{ }^{-1}$. Overall, our results indicate the robustness of the cornstalk test to the number of nodes included in the sample, the losses of pith from some cornstalks due to insect damage and minor displacement in cutting during the collection of stalks. 


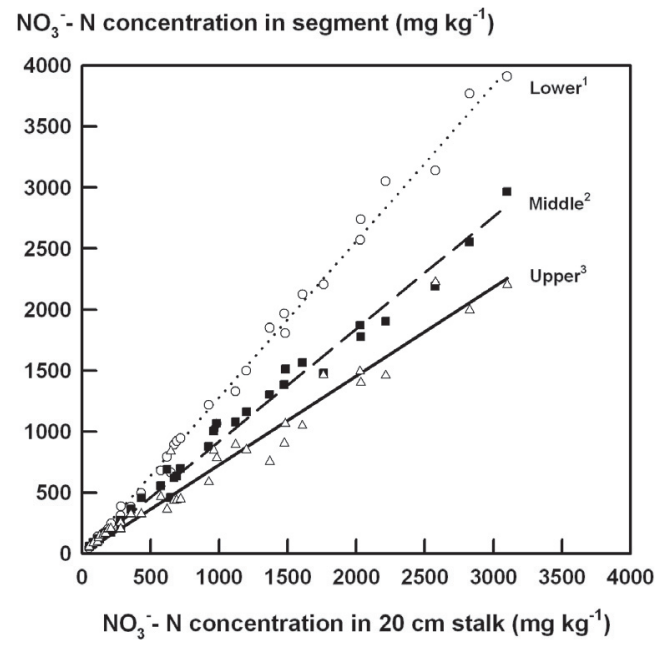

Figure 3. Relationships between the nitrate concentration in different segments of the stalk and nitrate concentration in the standard (20-cm) cornstalk sample.

${ }^{1} 15-21.5 \mathrm{~cm}$ from soil; $\mathrm{Y}=1.28 \mathrm{X}, \mathrm{R}^{2}=0.99$.

2 21.5-28 cm from soil; $\mathrm{Y}=0.92 \mathrm{X}, \mathrm{R}^{2}=0.99$.

${ }^{3} 28-35 \mathrm{~cm}$ from soil; $\mathrm{Y}=0.73 \mathrm{X}, \mathrm{R}^{2}=0.96$.

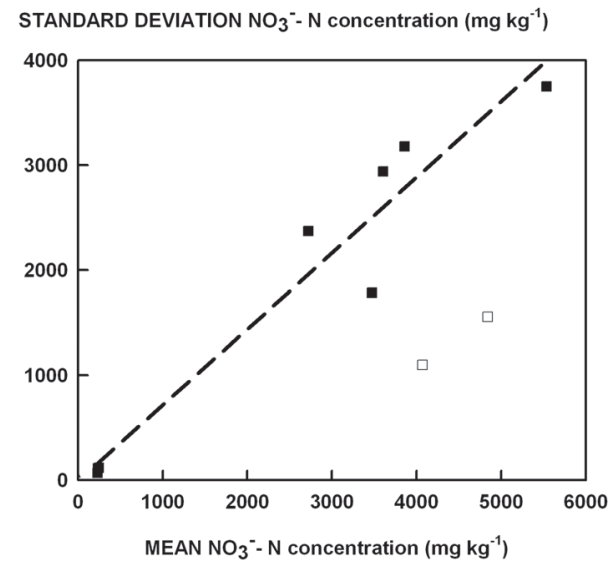

Figure 4. Relationship between the mean of the end-of-season nitrate concentrations and its standard deviation. $\mathrm{Y}=0.72 \mathrm{X}, \mathrm{R}^{2}=0.94$. Two pieces of data (open square symbol) were not included in the regression and considered outliers because their absolute Studentized residuals were greater than 1.8 .

\subsection{Variability among cornstalks}

The standard deviation of nitrate concentrations for individual samples tended to increase with increases in the weighted mean nitrate concentration for the sample (Fig. 4). This should be expected because of the extremely wide range in concentrations often found in the samples. Good relationships should not be expected because the plot could reasonably differ in the extent to which $\mathrm{N}$ sufficiency varies among plants. This variability could be due to spatial variability in supply of plantavailable $\mathrm{N}$ or amounts of $\mathrm{N}$ needed by the plants.

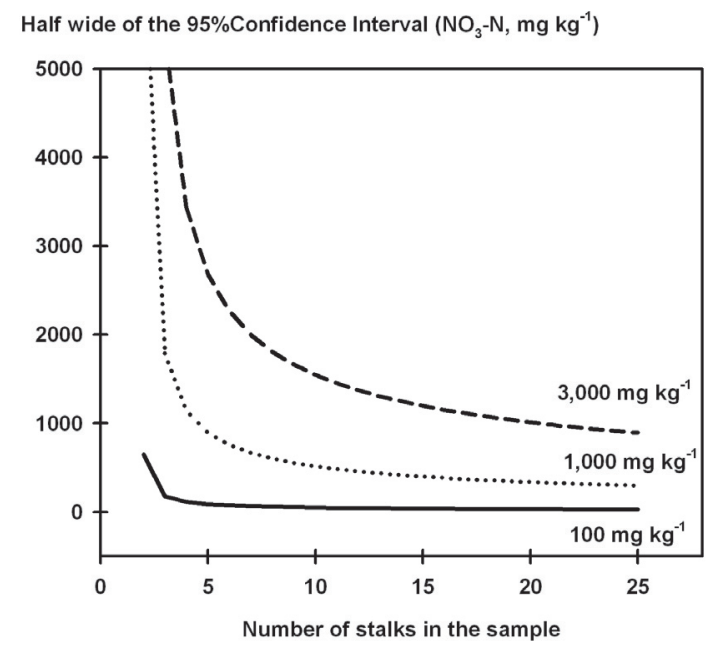

Figure 5. Effect of increasing the number of stalks in the sample on the accuracy of the mean. The relationship is presented for samples averaging 100, 1000 and $3000 \mathrm{mg} \mathrm{kg}^{-1}$ of $\mathrm{NO}_{3}-\mathrm{N}$.

Variability in $\mathrm{N}$ sufficiency among individual plants within a plot, or a small area of seemingly uniform soil, is an objective measurement of uniformity in the plot (or area) assumed to be uniform when samples are collected. In the absence of past information concerning the amount of variability normally expected, we propose the relationship presented in Figure 4 when discussing variability within plots. The expected relationship is that the standard deviation is normally about $72 \%$ of the mean. Without making the presumption that this relationship is valid for all conditions, this relationship can be used when characterizing the amounts of variability expected or found.

Figure 5 shows the relationships between the $95 \%$ confidence intervals for measured stalk nitrate concentrations and the number of stalk segments included in a sample. The confidence intervals were calculated using the relationship between the mean and standard deviation shown in Figure 4. The data presented indicate that confidence intervals should be expected to increase rapidly when less than 10 stalk segments per sample are collected, and that little is gained by collecting more than 15 stalk segments per sample. Thus, increasing the number of stalks from 10 to 15 will decrease the half-width of the confidence interval from 52 to $40 \mathrm{mg} \mathrm{kg}^{-1}$ for samples testing $100 \mathrm{mg} \mathrm{kg}^{-1}$, from 515 to 399 for samples testing $1000 \mathrm{mg} \mathrm{kg}^{-1}$ and from 1545 to 1196 for samples testing $3000 \mathrm{mg} \mathrm{kg}^{-1}$.

\subsection{Reduction in the length of the cornstalk sampled}

There is a significant $(P<0.001)$ linear correlation $\left(\mathrm{R}^{2}=\right.$ 0.99 , Fig. 6) between the nitrate concentration in the small and large samples.

The intercept is not significantly different from zero $(P>$ $0.1)$ but the slope is significantly $(P<0.01)$ different from one. Considering that the precision of plant nitrate analysis using the selective electrode was approximately 5\% under 


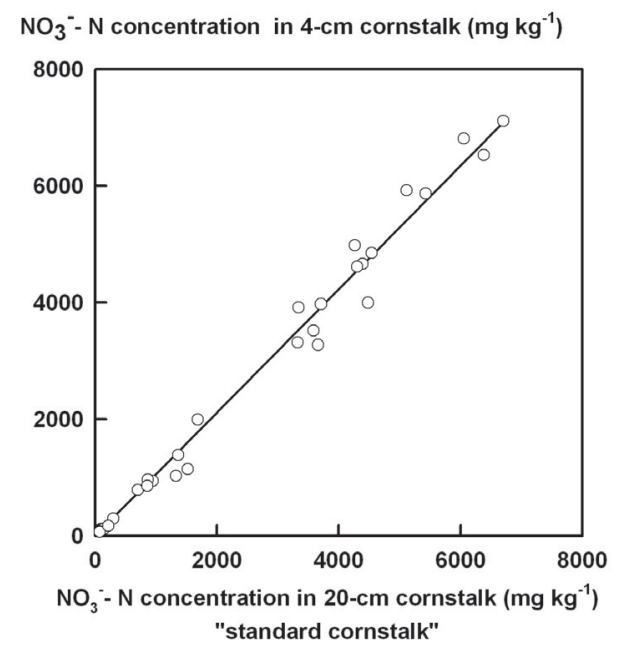

Figure 6. Relationship between the $\mathrm{NO}_{3}-\mathrm{N}$ concentrations in the small (4-cm length) and standard (20-cm length) samples. $\mathrm{Y}=$ $1.058 \mathrm{X}, \mathrm{R}^{2}=0.99$.

our laboratory conditions, the $6 \%$ of discrepancy between the small and large samples seems to be not important from a practical point of view. These small differences may in part be associated with the fact that the 4-cm segment was cut without taking special care over the part along the $20-\mathrm{cm}$ cornstalk at which it was taken. However, this procedure could increase the error if all the 4-cm segments of the sample were collected further away from or near to the base of the plant because of the significant gradient in nitrate concentrations along the cornstalk (Fig. 3). Therefore, the relationship shown in Figure 6 should improve if the small segment of 4-cm length is selected near the central part of the cornstalk (between 18 and $22 \mathrm{~cm}$ above the ground). This result indicates that a smaller segment, instead of that usually collected following the current recommendations (Blackmer and Mallarino, 1997) for the end-of-season cornstalk test, could be collected. A verification of this result in a more extensive field study would allow the simplification of the standard procedure, reducing the amount of plant material to collect, dry and grind.

\section{CONCLUSION}

Our study shows that minor deviations in sampling methods are not likely to be a major source of error with the end-ofseason test for cornstalk nitrate. However, the extremely wide range of stalk nitrate concentrations makes it difficult to assess the potential source of errors in studies that do not include relatively high or low values. Although for normal purposes the end-of-season cornstalk test seems to be quite robust in relation to the number of nodes, the proportion rind/pith, and the length of the segment sampled, for scientific work a careful sampling is recommended in order to get higher confidence in the results. A minimum of 10 stalk segments should be collected to attain an acceptable precision. In addition, it seems feasible to reduce the length of the cornstalk from 20 to about $4 \mathrm{~cm}$, maintaining the original critical values proposed by Binford et al. (1992), although more extensive research should be conducted before extending this recommendation to maize growers.

Acknowledgements: This work is dedicated to the memory of Professor Alfred M. Blackmer (Ames, Iowa State University), the inspiration for this research, who passed away on January 28th 2006. Thanks are given to N.A.T.O. for the fellowship provided to R. Isla for his postdoctoral course in the Agronomy Department at Iowa State University during 1998.

\section{REFERENCES}

Abad A., Michelena A., Lloveras J. (2006) Effects of nitrogen supply on wheat and on soil nitrate, Agron. Sustain. Dev. 25, 439-446.

Balkcom K.S., Blackmer A.M., Hansen D.J., Morris T.F., Mallarino A.P. (2003) Testing soils and cornstalks to evaluate nitrogen management on the wastershed scale, J. Environ. Qual. 32, 1015-1024.

Binford G.D., Blackmer A.G., El-Hout N.M. (1990) Tissue Test for Excess Nitrogen during Corn Production, Agron. J. 82, 124-129.

Binford G.D., Blackmer A.G., Meese B.G. (1992) Optimal Concentrations of nitrate in Cornstalks at Maturity, Agron. J. $84,881-887$

Blackmer A.M., Mallarino A.P. (1997) Cornstalk testing to evaluate nitrogen management. University Extension Pm-1584, Iowa State University, Ames, Iowa.

Blackmer A.M., White S.E. (1998) Using precision farming technologies to improve management of soil and fertilizer nitrogen, Aust. J. Agr. Res. 49, 555-564.

Deutsch B., Kahle P., Voss M. (2006) Assessing the source of nitrate pollution in water using stable N and O isotopes, Agron. Sustain. Dev. $26,263-268$.

Friedrich J.W., Shrader L.E., Nordheim E.V. (1979) N Deprivation in Maize during Grain Filling. I. Accumulation of Dry Matter, NitrateN, Sulfate-S, Agron. J. 71, 461-465.

Granstedt R.C., Huffaker R.C. (1982) Identification of the Leaf Vacuole as a Major Nitrate Storage Pool, Plant Physiol. 70, 410-413.

Isidoro D., Quilez D., Aragüés R. (2006) Environmental impact of irrigation in La Violada District (Spain): II. Nitrogen fertilization and nitrate export patterns in drainage water, J. Environ. Qual. 35, 776-785.

Justes E. Mary B., Meynard J.M., Machet J.M., Thelierhuche L. (1994) Determination of a Critical Nitrogen Dilution Curve for WinterWheat Crops, Ann. Bot. 74, 397-407.

Murphy L.S., Smith G.E. (1967) Nitrate Accumulations in Forage Crops, Agron. J. 59, 171-182.

Sheehy J.E., Dionora M.J.A., Mitchell P.L., Peng S., Cassman K.G., Lemaire G., Williams R.L. (1998) Critical nitrogen concentrations: implications for high-yielding rice (Oryza sativa L.) cultivars in the tropics, Field Crops Res. 59, 31-41.

Wilhelm W.W., Arnold S.L., Schepers J.S. (2000) Using a nitrate specific ion electrode to determine stalk nitrate-nitrogen concentration, Agron. J. 92, 186-189.

Wilhelm W.W., Varvel G.E., Schepers J.S. (2005) Corn stalk nitrate concentration profile, Agron. J. 97, 1502-1507.

Zhen R.G., Leigh R.A. (1990) Nitrate Accumulation by Wheat (Triticum aestivum) in Relation to Growth and Tissue-N Concentrations, Plant Soil 124, 157-160. 